UDC 577.29

\title{
Identification of $\mathrm{Ca}^{2+} /$ calmodulin-dependent phosphorylation sites of endocytic scaffold ITSN1 by tandem mass spectrometry
}

\author{
D. Ye. Morderer ${ }^{1}$, O. V. Nikolaienko ${ }^{2}$, A. V. Rynditch ${ }^{1}$ \\ ${ }^{1}$ Institute of Molecular Biology and Genetics, NAS of Ukraine \\ 150, Akademika Zabolotnoho Str., Kyiv, Ukraine, 03680 \\ ${ }^{2}$ Department of Biomedicine, University of Bergen, \\ Jonas Lies vei 91, Bergen, Norway, 5009 \\ d.y.morderer@imbg.org.ua
}

\begin{abstract}
ITSN1 is a scaffold protein involved in endocytosis, signal transduction and cytoskeleton regulation. It has been previously shown that ITSN1 undergoes $\mathrm{Ca}^{2+} /$ calmodulin-dependent phosphorylation in vitro. Aim. We intend to identify these phosphorylation sites. Methods. In vitro kinase reaction; liquid chromatography-tandem mass spectrometry (LC/MS/MS). Results. We identified five sites of $\mathrm{Ca}^{2+} /$ calmodulin-dependent phosphorylation in the recombinant fragments of ITSN1. Conclusions. We have shown that the ITSN1 coiled-coil region (CCR) and the interdomain linkers between $\mathrm{EH} 2$ and $\mathrm{CCR}, \mathrm{SH} 3 \mathrm{~A}$ and $\mathrm{SH} 3 \mathrm{~B}, \mathrm{SH} 3 \mathrm{~B}$ and $\mathrm{SH} 3 \mathrm{C}$ domains were phosphorylated in a $\mathrm{Ca}^{2+} /$ calmodulin-dependent manner in vitro.
\end{abstract}

Ke y w o r d s: ITSN1, $\mathrm{Ca}^{2+}$, phosphorylation, LC/MS/MS.

\section{Introduction}

ITSN1 is a scaffold protein implicated in various cellular processes including the endocytosis, signal propagation through a number of signaling pathways, actin cytoskeleton regulation, etc [1]. Accumulating evidence connects ITSN1 misregulation with the neurodevelopmental and neurodegenerative disorders, such as Down syndrome, Alzheimer's disease and Huntington's disease [2-4]. It is believed that ITSN1 operates in a cell by interacting with the partner molecules, thereby promoting an assembly of macromolecular complexes. As for today, dozens of ITSN1 interactors are already known and their number continues to increase [5]. Such complexity implies the existence of precise regulatory mechanisms which control the dynamics of interaction and the selection of partner molecules for ITSN1 binding. The post-translational modifications of ITSN1 can potentially be involved in these mechanisms.

Phosphorylation is one of the most widespread and well studied post-translational modifications of proteins. It results in the covalent attachment of phosphate group to the serine, threonine or tyrosine residues, which can lead to an alteration in the protein conformation and subsequent change of its properties. Therefore, phosphorylation is a common mechanism for triggering the protein activation state. ITSN1 phosphorylation has been already revealed in several large-scale studies of phosphoproteome in different tissues [6-9]. Additionally, the tyrosine phosphorylation of ITSN1 in response to the overexpression of Epstein-Barr virus protein LMP2A and tyrosine kinase Syk in HEK293 cells has been reported [10]. However, it is unclear which intracellular pathways

(C) 2015 D. Ye. Morderer et al.; Published by the Institute of Molecular Biology and Genetics, NAS of Ukraine on behalf of Biopolymers and Cell. This is an Open Access article distributed under the terms of the Creative Commons Attribution License (http://creativecommons.org/licenses/by/4.0/), which permits unrestricted reuse, distribution, and reproduction in any medium, provided the original work is properly cited 
Identification of $\mathrm{Ca}^{2+} /$ calmodulin-dependent phosphorylation sites of endocytic scaffold ITSN1 by tandem mass spectrometry

$A$

ITSN1

EH EH DH

$B$

CCR

SH3A-E

CCR

312_RSGSGISVISSTSVDQRLPEEPVLEDEQQQLEKKLPVTFEDKKRENFERGNLELEKRRQALLEQQR KEQERLAQLERAEQERKERERQEQERKRQLELEKQLEKQRELERQREEERRKEIERREAAKRELERQRQLEWERNRRQ ELLNQRNKEQEDIVVLKAKKKTLEFELEALNDKKHQLEGKLQDIRCRLTTQRQEIESTNKSRELRIAEITHL QQQLQESQQMLGRLIPEKQILNDQLKQVQQNSLHRDSLVTLKRALEAKELARQHLRDQLDEVEKETRS KLQEIDIFNNQLKELREIHNKQQLQKQKSMEAERLKQKEQERKIIELEKOKEEAQRRAQERDKQWLEHVQ QEDEHQRPRKLHEEEKLKREESVKKKDGEEKGKQEAQDKLGRLFHQHQEP_715

\section{SH3A-E}

718_PAVQAPWSTAEKGPLTISAQENVKVVYYRALYPFESRSHDEITIQPGDIVMVKGEWVDESQTGEPGWLGGE LKGKTGWFPANYAEKIPENEVPAPVKPVTDSTSAPAPKLALRETPAPLAVTSSEPSTTPNNWADFSSTWPTST NEKPETDNWDAWAAQPSLTVPSAGQLRQRSAFTPATATGSSPSPVLGQGEKVEGLQAQALYPWRAKKDNHLNF NKNDVITVLEQQDMWWFGEVQGQKGWFPKSYVKLISGPIRKSTSMDSGSSESPASLKRVASPAAKPV VSGEEFIAMYTYESSEQGDLTFQQGDVILVTKKDGDWWTGTVGDKAGVFPSNYVRLKDSEGSGTAGKTGSLGK KPEIAQVIASYTATGPEQLTLAPGQLILIRKKNPGGWWEGELQARGKKRQIGWFPANYVKLLSPGTSKI TPTEPPKSTALAAVCQVIGMYDYTAQNDDELAFNKGQIINVLNKEDPDWWKGEVNGQVGLFPSNYV KLTTDMDPSQQ_1220

drive these phosphorylation events. Recently, we have demonstrated that the CCR and SH3A-E fragments of ITSN1, containing the coiled-coil region and SH3 domains, respectively (Fig. 1A), can be phosphorylated in the $\mathrm{Ca}^{2+} /$ calmodulin-dependent manner, suggesting the possibility of ITSN1 phosphorylation in response to the elevation of the intracellular $\mathrm{Ca}^{2+}$ concentration [11]. Here we report the identification of $\mathrm{Ca}^{2+} /$ calmodulin-dependent phosphorylation sites in ITSN1 using tandem mass spectrometry combined with liquid chromatography (LC/MS/MS).

\section{Materials and Methods}

\section{Plasmid constructions}

The plasmid encoding GST-fused CCR fragment of ITSN1 was described previously [12]. Nucleotide sequence encoding SH3A-E fragment of ITSN1 was PCR amplified and cloned in pGEX-4T-2 vector (GE Healthcare, USA).

Recombinant protein expression and purification.

Recombinant GST-fused proteins were expressed using Escherichia coli BL21(DE3) strain. Obtained proteins were affinity-purified using glutathionesepharose 4B (GE Healthcare, USA) according to manufacturer's instruction.
Fig. 1. $A$ - Schematic representation of ITSN1 domain structure. Domains studied in this work are underlined. $B-$ Aminoacid sequences of studied fragments of ITSN1. Peptides identified by mass spectrometry are enlarged and underlined. Peptides identified after treatment with trypsin are highlighted in bold. Peptides identified after treatment with Glu-C are in italics

\section{In vitro kinase reaction}

The reaction was performed as described previously [11]. Briefly, calmodulin-binding proteins were purified from mouse brain lysate on calmodulin-agarose beads (Sigma-Aldrich, USA), dialyzed against kinase buffer (50 mM Tris- $\mathrm{HCl} \mathrm{pH} 7.5,10 \mathrm{mM} \mathrm{MgCl}, 2 \mathrm{mM}$ DTT) and then mixed with purified recombinant ITSN1 fragments. The reaction was supplied by $0.4 \mathrm{mM}$ EGTA, $0.5 \mu \mathrm{M}$ microcystin, $100 \mu \mathrm{M}$ ATP, $3 \mu \mathrm{M}$ calmodulin, $2 \mathrm{mM} \mathrm{CaCl}_{2}$, and incubated at $30{ }^{\circ} \mathrm{C}$ for 30 $\mathrm{min}$. Then the reaction was stopped by addition of an equal volume of Laemmli sample buffer $(150 \mathrm{mM}$ Tris- $\mathrm{HCl} \mathrm{pH}$ 6.8, $2.5 \%$ glycerol, 10\% SDS, $3 \%$ $\beta$-mercaptoethanol and $0.5 \%$ bromophenol blue). After boiling the samples were resolved by SDS-PAGE and stained by Coomassie Brilliant Blue.

\section{$L C / M S / M S$}

In-gel digestion of proteins was performed at $37^{\circ} \mathrm{C}$ overnight with trypsin or Glu-C proteases (Roche, Switzerland) (1:50 protease : protein ratio). Next day the peptides were extracted from the gel using Oasis C18 kit. Then, the peptides were dissolved to a final concentration of $4 \%$ in formic acid before analysis on LTQ Orbitrap Velos Pro mass spectrometer (Thermo Fischer Scientific, USA) equipped with a 
nano spray Flex ion source (Thermo Fischer Scientific, USA), coupled to a Dionex Ultimate NCS3000 LC system (Thermo Fischer Scientific, USA). Fragmentation of primary ions was performed by HCD (high-energy collision dissociation) technique. Tandem mass spectra were extracted by Proteome Discoverer $^{\mathrm{TM}}$ software (Thermo Scientific, USA). Charge state deconvolution and deisotoping were not performed. All MS/MS samples were analyzed using Mascot (Matrix Science, London, UK; version 1.3.0.339). Mascot was set up to search Mascot5 SwissProt_Homo sapiens (human) (16369 entries) assuming the digestion enzyme trypsin or V8. Mascot was searched with a fragment ion mass tolerance of $0.05 \mathrm{Da}$ and a parent ion tolerance of 15 PPM. Iodoacetamide derivative of cysteine was specified in Mascot as a fixed modification. Oxidation of methionine, acetylation of the N-terminus and phosphorylation of serine and threonine were specified in Mascot as variable modifications. The phosphopeptides with reliably identified phosphorylation site were selected by the value of Mascot Delta Ion Score, using value 13 as a threshold [13]. Their spectra were also manually revised using Scaffold software version 3.6.5 (Proteome Software) [14].

\section{Results and Discussion}

In order to identify the sites of $\mathrm{Ca}^{2+} /$ calmodulindependent phosphorylation in the ITSN1 recombi- nant fragments we repeated our previously described assay for in vitro $\mathrm{Ca}^{2+} /$ calmodulin-dependent phosphorylation [11] and subsequently analyzed the samples by LC/MS/MS. To increase the sequence coverage and probability of identification for all possible phosphosites, the samples were divided and digested independently by two distinct endoproteases: trypsin and Glu-C. As a result of the mass spectrometric peptide detection we obtained $48.7 \%$ coverage for CCR sequence and $59.4 \%$ coverage for SH3A-E sequence using trypsin, whereas for Glu-C the corresponding values were $39.1 \%$ and $23.3 \%$, respectively. In summary we obtained $61.6 \%$ and $67.4 \%$ sequence coverage for CCR and SH3A-E fragments, respectively (Fig. $1 B$ ).

For each digestion variant except the SH3A-E fragment digested by Glu-C we were able to identify a number of phosphopeptides (Supplementary Table 1). The obtained phosphopeptides were sorted according to their calculated Mascot Delta Ion Score value to select those with the most confidently located phosphorylation sites. In this way we identified five phosphopeptides containing the phosphorylation sites corresponding to positions T349, T567, S624, S904 and S978 in ITSN1 sequence (Q15811 in UniProtKB database) (Table 1). We also carefully checked the MS/MS spectra of selected peptides manually for the presence of phosphospecific secondary ions to confirm a reliable location of the phosphorylated sites (Fig. 2).

Table 1. Identification of Phosphorylation Sites in ITSN1 Fragments by LC/MS/MS

\begin{tabular}{|c|c|c|c|c|c|c|c|c|}
\hline Peptide Sequence & 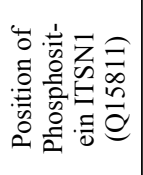 & 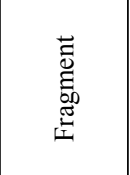 & $\begin{array}{c}\text { Protease } \\
\text { Used }\end{array}$ & 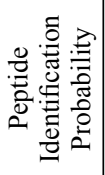 & 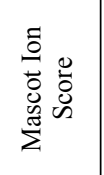 & $\begin{array}{l}\text { Mascot } \\
\text { Identity } \\
\text { Score }\end{array}$ & $\begin{array}{l}\text { Mascot Delta } \\
\text { Ion Score }\end{array}$ & 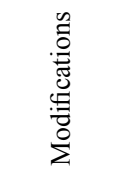 \\
\hline (R)DSLVtLKR(A) & 567 & CCR & Trypsin & $95 \%$ & 57.93 & 28.5248 & 19.68 & $\begin{array}{c}\text { Phospho } \\
(+80)\end{array}$ \\
\hline (K)KLPVtFEDK(K) & 349 & CCR & Trypsin & $95 \%$ & 35.35 & 25.0 & 35.35 & $\begin{array}{l}\text { Phospho } \\
(+80)\end{array}$ \\
\hline (E)IHNKQQLQKQKsMEAERLKQKE(Q) & 624 & CCR & Glu-C & $95 \%$ & 35.18 & 26.374897 & 35.18 & $\begin{array}{l}\text { Phospho } \\
(+80)\end{array}$ \\
\hline (R)SAFTPATATGSSPsPVLGQGEK(V) & 904 & SH3A-E & Trypsin & $95 \%$ & 86.77 & 25.0 & 15.0099945 & $\begin{array}{c}\text { Phospho } \\
(+80)\end{array}$ \\
\hline (K)STsMDSGSSESPASLKR(V) & 978 & SH3A-E & Trypsin & $95 \%$ & 117.05 & 29.604706 & 16.410004 & $\begin{array}{l}\text { Phospho } \\
(+80)\end{array}$ \\
\hline
\end{tabular}


A

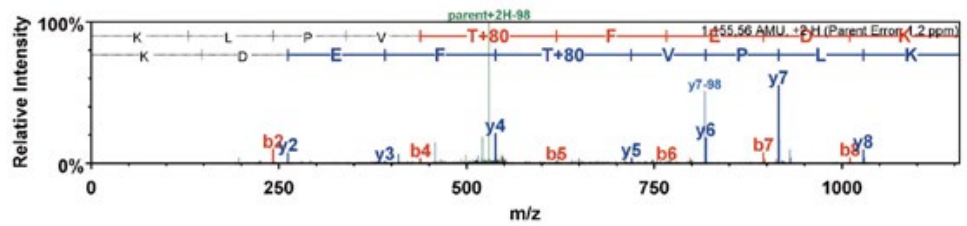

$B$

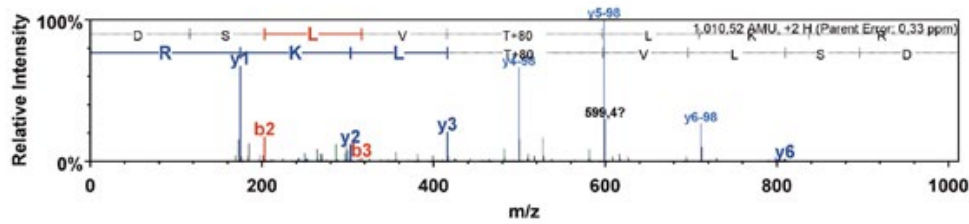

C

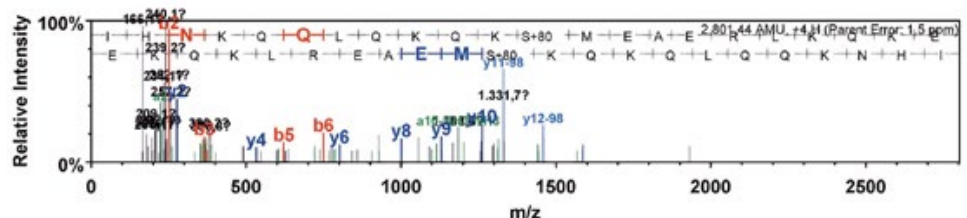

D

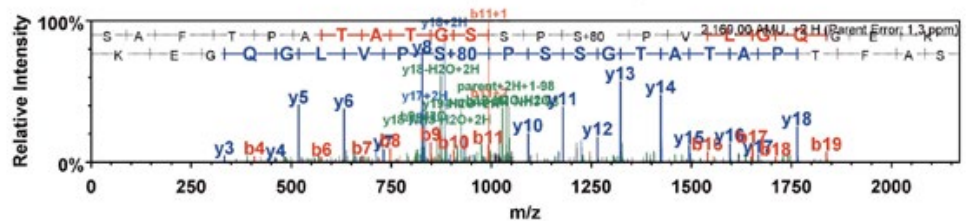

E

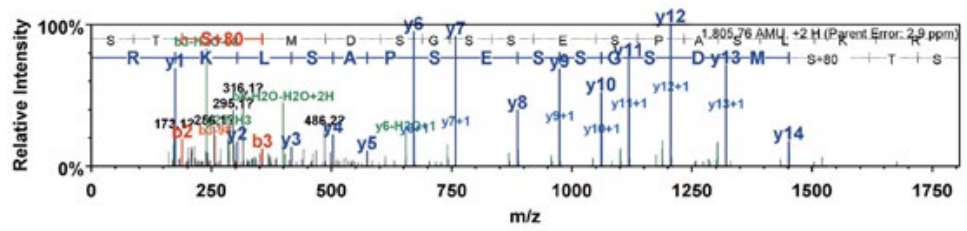

A

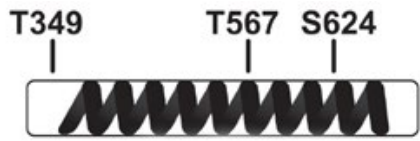

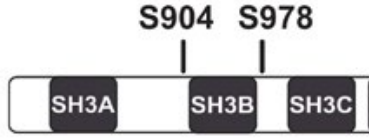

SH3D
Fig. 2. HCD MS/MS spectra of identified phosphopeptides. $A-\mathrm{HCD}$ spectrum of $(\mathrm{K})$ KLPVpTFEDK(K) (residues 345-353). The most intensive peak corresponds to the neutral loss of $\mathrm{H}_{3} \mathrm{PO}_{4}$ from parental ion (-98), indicating phosphorylation of the peptide. $B-\mathrm{HCD}$ spectrum of (R)DSLVpTLKR(A) (residues 563-570). Phosphorylation of T567 is confirmed by the presence of y4, y5 and $y 6$ ions with the neutral losses of $\mathrm{H}_{3} \mathrm{PO}_{4}$ (-98). $C$ - HCD spectrum of (E)IHNKQQLQKQKpSMEAERLKQKE(Q) (residues 613-634). Phosphorylation of S624 is indicated by y11 and y12 ions with the neutral losses of H3PO4 (-98). D - HCD spectrum of(R)SAFTPATATGSSPpSPVLGQGEK(V) (residues 891-912). Phosphorylation of the peptide is indicated by parental ion with the neutral loss of $\mathrm{H}_{3} \mathrm{PO}_{4}$ (-98). Assignment of phosphorylation to $\mathrm{S} 904$ site is justified by the presence of y10 ion. $E-\mathrm{HCD}$ spectrum of (K)STpSMDSGSSESPASLKR(V) (residues 976-992). Phosphorylation of S978 [is] indicated by $\mathrm{b} 2$ and $\mathrm{b} 3$ ions, as well as by the presence of $\mathrm{b} 3$ ions containing losses of $\mathrm{H}_{3} \mathrm{PO}_{4}(-98)$ and $\mathrm{H}_{2} \mathrm{O}^{+} \mathrm{H}_{3} \mathrm{PO}_{4}(-116)$
$B$

\section{0}

KVVYYRALYPFESRSHDEITIQPGDIVMVKGEWVDESQTGEPGWLGGELKG SH3A DOMAIN

KTGWFPANYAEKIPENEVPAPVKPVTDSTSAPAPKLALRETPAPLAVTSSEPSTTPN

NWADFSSTWPTSTNEKPETDNWDAWAAQPSLTVPSAGQLRQRSAFTPATATGSS

PSPVLGQGEKVEGLQAQALYPWRAKKDNHLNFNKNDVITVLEQQDMWWFGEVQ SH3B DOMAIN

GQKGWFPKSYVKLISGPIRKSTSMDSGSSESPASLKRVASPAAKPVVSGEEFIAMY

\section{TYESSEQGDLTFQQGDVILVTKKDGDWWTGTVGDKAGVFPSNYVRLKDS 1060 SH3C DOMAIN}

Fig. 3. $A$ - Location of phosphorylation sites within the fragments of ITSN1. $B-$ Partial sequence of SH3A-E between SH3A and SH3C domains. Domain sequences are shown in grey. Serine/threonine residues within domains are shown in blue and within interdomain linkers - in red. Frequency of occurrence of serine/threonine residues in the interdomain linkers is higher than inside domains 
Among the identified phosphorylation sites, only S624 and S978 match the R/K-X-X-S/T canonical recognition motif for $\mathrm{Ca}^{2+} /$ calmodulin-dependent kinases [15]. Amino acid sequences of other sites do not resemble the known kinase recognition motifs, thus making a kinase responsible for these phosphorylation events difficult to predict. However, it is known that the absence of full match with the consensus motif does not mean the inability of a particular kinase to phosphorylate a given substrate. For instance, it has been shown that cyclin-dependent linase CDK1 under certain condition can phosphorylate the minimal $\mathrm{S} / \mathrm{T}-\mathrm{P}$ recognition motif instead of the canonical S/T-P-X-K/R motif $[16,17]$. Interestingly, the identified S904 site corresponds to this minimal motif. Additionally, the S904 phosphorylation site is flanked by proline residues, indicating its possible phosphorylation by so called proline-directed kinases, which include the CDK, MAPK, JNK and GSK kinase families [18]. Interestingly, CDK4 and CDK5 can interact with calmodulin and be activated by either $\mathrm{Ca}^{2+}$ or $\mathrm{Ca}^{2+}-$ dependent phosphorylation [19-22], suggesting the possibility of their presence in our purified calmodulin-binding fraction and the activation in $\mathrm{Ca}^{2+}$ dependent manner. Notably, the S904 phosphorylation has already been detected in the large-scale studies of phosphoproteome [6-9].

For S349 and T567 it is hard to predict a kinase that could phosphorylate these residues. Interestingly, both of them are surrounded by hydrophobic amino acids (at positions $-2,-1$ and +1 ), suggesting their modification by the same kinase.

A functional role of the identified phosphorylation sites is unclear and needs to be studied in future experiments. The T567 and S624 sites are located in the coiled-coil region of ITSN1 (Fig.3A). This domain mediates its oligomerization or interactions with other proteins containing similar domains [23]. It has been shown that phosphorylation of the threonine residues within such regions can destabilize helices, whereas phosphorylation of the serine residues can lead to either their stabilization or destabilization [24, 25]. It can be expected that the phosphorylation events with- in the coiled-coil region can affect its ability to oligomerize or interact with other proteins. T349, S904 and S904 are located in the interdomain linkers that are predicted to be intrinsically disordered (Fig. 3A). It has been demonstrated that phosphorylation of the serine and threonine residues most often occurs in such regions [26-28]. Moreover, the S904 and S978 sites are located within the regions enriched in the serine/threonine residues (Fig. $3 B$ ). Phoshorylation of several residues in these clusters has been identified [6-8]. Interestingly, these two clusters are located at both sides and in close proximity to the SH3B domain. Therefore, we suggest that phosphorylation of the serine and threonine residues belonging to these clusters can affect the SH3B domain ability to mediate protein-protein interactions. We believe that examination of the role of identified phosphorylation sites in the ITSN1 function is a promising direction for further investigations.

\section{Conclusions}

We showed that ITSN1 coiled-coil region (CCR) and interdomain linkers between the $\mathrm{EH} 2$ and $\mathrm{CCR}$, SH3A and SH3B, SH3B and SH3C domains were phosphorylated in $\mathrm{Ca}^{2+} /$ calmodulin-dependent manner in vitro.

\section{Funding.}

This work was supported by joint project between NAS of Ukraine and CNRS "From Molecular to Cellular Events in Human Pathologies" (№0113U002831).

\section{REFERENCES.}

1. Tsyba LO, Dergai MV, Skrypkina IYa, Nikolaienko OV, Dergai OV, Kropyvko SV, Novokhatska OV, Morderer DYe, Gryaznova TA, Gubar OS, Rynditch $A V$. ITSN protein family: regulation of diversity, role in signalling and pathology. Biopolym Cell. 2013; 29(3):244-51.

2. Pucharcós C, Fuentes JJ, Casas C, de la Luna S, Alcántara $S$, Arbonés ML, Soriano E, Estivill X, Pritchard M. Alusplice cloning of human Intersectin (ITSN), a putative multivalent binding protein expressed in proliferating and differentiating neurons and overexpressed in Down syndrome. Eur J Hum Genet. 1999;7(6):704-12. 
Identification of $\mathrm{Ca}^{2+} /$ calmodulin-dependent phosphorylation sites of endocytic scaffold ITSN1 by tandem mass spectrometry

3. Wilmot B, McWeeney SK, Nixon RR, Montine TJ, Laut J, Harrington CA, Kaye JA, Kramer PL. Translational gene mapping of cognitive decline. Neurobiol Aging. 2008;29(4):524-41.

4. Scappini E, Koh TW, Martin NP, O’Bryan JP. Intersectin enhances huntingtin aggregation and neurodegeneration through activation of c-Jun-NH2-terminal kinase. Hum Mol Genet. 2007;16(15):1862-71.

5. Hunter MP, Russo A, O'Bryan JP. Emerging roles for intersectin (ITSN) in regulating signaling and disease pathways. Int J Mol Sci. 2013;14(4):7829-52.

6. Ballif BA, Villén J, Beausoleil SA, Schwartz D, Gygi SP. Phosphoproteomic analysis of the developing mouse brain. Mol Cell Proteomics. 2004;3(11):1093-101.

7. Dephoure N, Zhou C, Villén J, Beausoleil SA, Bakalarski CE, Elledge SJ, Gygi SP. A quantitative atlas of mitotic phosphorylation. Proc Natl Acad Sci US A. 2008;105(31):10762-7.

8. Villén J, Beausoleil SA, Gerber SA, Gygi SP. Large-scale phosphorylation analysis of mouse liver. Proc Natl Acad Sci U S A. 2007;104(5):1488-93.

9. Beausoleil SA, Jedrychowski M, Schwartz D, Elias JE, Villén J, Li J, Cohn MA, Cantley LC, Gygi SP. Large-scale characterization of HeLa cell nuclear phosphoproteins. Proc Natl Acad Sci U S A. 2004;101(33):12130-5.

10. Dergai O, Dergai M, Skrypkina I, Matskova L, Tsyba L, Gudkova D, Rynditch A. The LMP2A protein of EpsteinBarr virus regulates phosphorylation of ITSN1 and Shb adaptors by tyrosine kinases. Cell Signal. 2013;25(1):3340.

11. Morderer DYe, Nikolaienko OV, Skrypkina IYa, Rymarenko OV, Kropyvko SV, Tsyba LO, Rynditch AV. Ca/calmodulindependent phosphorylation of endocytic scaffold ITSN1. Biopolym Cell. 2014; 30(1):74-6.

12. Nikolaienko O, Skrypkina I, Tsyba L, Fedyshyn Y, Morderer D, Buchman V, de la Luna S, Drobot L, Rynditch A. Intersectin 1 forms a complex with adaptor protein Ruk/CIN85 in vivo independently of epidermal growth factor stimulation. Cell Signal. 2009;21(5):753-9.

13. Savitski MM, Lemeer $S$, Boesche M, Lang M, Mathieson T, Bantscheff $M$, Kuster B. Confident phosphorylation site localization using the Mascot Delta Score. Mol Cell Proteomics. 2011;10(2):M110.003830.

14. Searle $B C$. Scaffold: a bioinformatic tool for validating MS/ MS-based proteomic studies. Proteomics. 2010;10(6):1265-9.

15. Pearson RB, Woodgett JR, Cohen P, Kemp BE. Substrate specificity of a multifunctional calmodulin-dependent protein kinase. J Biol Chem. 1985;260(27):14471-6.

16. Ubersax JA, Woodbury EL, Quang PN, Paraz M, Blethrow JD, Shah K, Shokat KM, Morgan DO. Targets of the cyclindependent kinase Cdk1. Nature. 2003;425(6960):859-64.

17. Rudner AD, Murray AW. Phosphorylation by Cdc 28 activates the $\mathrm{Cdc} 20$-dependent activity of the anaphase-promoting complex. J Cell Biol. 2000;149(7):1377-90.
18. Lu KP, Liou YC, Zhou XZ. Pinning down proline-directed phosphorylation signaling. Trends Cell Biol. 2002;12(4):164-72.

19. Taulés $M$, Rius E, Talaya D, López-Girona A, Bachs O, Agell N. Calmodulin is essential for cyclin-dependent kinase $4(\mathrm{Cdk} 4)$ activity and nuclear accumulation of cyclin D1-Cdk4 during G1. J Biol Chem. 1998;273(50):33279-86.

20. Huber RJ, Catalano A, O'Day DH. Cyclin-dependent kinase 5 is a calmodulin-binding protein that associates with puromycin-sensitive aminopeptidase in the nucleus of Dictyostelium. Biochim Biophys Acta. 2013;1833(1):11-20.

21. Kahl CR, Means AR. Regulation of cyclin D1/Cdk4 complexes by calcium/calmodulin-dependent protein kinase I. $J$ Biol Chem. 2004;279(15):15411-9.

22. Zhen X, Goswami S, Abdali SA, Gil M, Bakshi K, Friedman $E$. Regulation of cyclin-dependent kinase 5 and calcium/ calmodulin-dependent protein kinase II by phosphatidylinositol-linked dopamine receptor in rat brain. Mol Pharmacol. 2004;66(6):1500-7.

23. Burkhard P, Stetefeld J, Strelkov SV. Coiled coils: a highly versatile protein folding motif. Trends Cell Biol. 2001;11(2):82-8.

24. Szilák L, Moitra J, Vinson C. Design of a leucine zipper coiled coil stabilized 1.4 kcal mol-1 by phosphorylation of a serine in the e position. Protein Sci. 1997;6(6):1273-83.

25. Szilák L, Moitra J, Krylov D, Vinson C. Phosphorylation destabilizes alpha-helices. Nat Struct Biol. 1997;4(2):112-4.

26. Dunker AK, Brown CJ, Lawson JD, Iakoucheva LM, Obradović $Z$. Intrinsic disorder and protein function. Biochemistry. 2002;41(21):6573-82.

27. Iakoucheva LM, Radivojac P, Brown CJ, O'Connor TR, Sikes JG, Obradovic Z, Dunker AK. The importance of intrinsic disorder for protein phosphorylation. Nucleic Acids Res. 2004;32(3):1037-49.

28. Collins MO, Yu L, Campuzano I, Grant SG, Choudhary JS. Phosphoproteomic analysis of the mouse brain cytosol reveals a predominance of protein phosphorylation in regions of intrinsic sequence disorder. Mol Cell Proteomics. 2008;7(7):1331-48.

\section{Ідентифікація сайтів $\mathrm{Ca}^{2+} /$ кальмодулін-залежного фосфорилювання скаффолдного білка ендоцитозу ITSN1 за допомогою тандемної мас-спектрометрії.}

\section{Д. Є. Мордерер, О. В. Ніколаєнко, А. В. Риндич.}

ITSN1 - це скафолдний білок, задіяний у процесах ендоцитозу, сигнальної трансдукції та регуляції цитоскелету. Раніше було показано, що ITSN1 підлягає $\mathrm{Ca}^{2+} /$ кальмодулін-залежному фосфорилюванню in vitro. Мета Ідентифікувати сайти цього фосфорилювання. Методи. In vitro кіназна реакція; рідинна хроматографія, поєднана 3 тандемною мас-спектрометрією (LC/MS/MS). Результати. Ми ідентифікували 5 сайтів $\mathrm{Ca}^{2+}$ кальмодулін-залежного фосфорилювання у рекомбінантних фрагментах ITSN1. Висновки. Було показано, що надспіралізована ділянка (CCR) та міждоменні лінкери між EH2 та CCR, 
SH3A та SH3B, а також між SH3B та SH3C доменами ITSN1 підлягають $\mathrm{Ca}^{2+} /$ кальмодулін-залежному фосфорилюванню.

Кл юч о в і сл о в а: ITSN1, $\mathrm{Ca}^{2+}$, фосфорилювання, LC/MS/ MS.

\section{Идентификация сайтов $\mathrm{Ca}^{2+} /$ кальмодулин-зависимого фосфорилирования скаффолдного белка эндоцитоза} ITSN1.

Д. Е. Мордерер, А. В. Николаенко, А. В. Рындич.

ITSN1 является скаффолдным белком, задействованным в процессах эндоцитоза, сигнальной трансдукции и регуляции цитоскелета. Ранее было показано, что ITSN1 подлежит $\mathrm{Ca}^{2+}$ кальмодулин-зависимому фосфорилированию in vitro. Цель
Идентифицировать сайты $\mathrm{Ca}^{2+} /$ кальмодулин-зависимого фосфорилирования ITSN1. Методы. In vitro киназная реакция, жидкостная хроматография в сочетании с тандемной массспектрометрией (LC/MS/MS). Результаты. Мы идентифицировали 5 сайтов $\mathrm{Ca}^{2+} /$ кальмодулин-зависимого фосфорилирования в рекомбинантных фрагментах ITSN1. Выводы. Было показано, что суперспирализированый участок (CCR) и междоменные линкеры между $\mathrm{EH} 2$ и CCR, SH3A и $\mathrm{SH} 3 \mathrm{~B}$, а также между SH3B и SH3C доменами ITSN1 подвергаются $\mathrm{Ca}^{2+} /$ кальмодулин-зависимому фосфорилированию.

Кл юч ев ы е сл ов а: ITSN1, $\mathrm{Ca}^{2+}$, фосфорилирование, LC/ MS/MS.

Received 03.07.2015 